\section{Growth and Development of 'Eckespoint Classic Red' Poinsettia in Biodegradable and Compostable Containers}

\author{
Roberto G. Lopez ${ }^{1}$ and Diane M. Camberato
}

ADDITIONAL INDEX WORDs. biocontainers, Euphorbia pulcherrima, pots, sustainability

SumMARY. Biodegradable, compostable, and traditional plastic containers were evaluated for production of 'Eckespoint Classic Red' poinsettia (Euphorbia pulcherrima), a long-term greenhouse crop (12-16 weeks transplant to finish, depending on cultivar). Containers were rated for appearance and durability during the 14-week production period and plant quality parameters were measured at anthesis. Plastic, rice hull, wheat starch-derived bioresin, and molded fiber containers remained unchanged in appearance and integrity and received a rating of 5 ( $1-5$ rating scale, where $\mathbf{l}=$ container integrity compromised substantially and $\mathbf{5}=$ container was intact, no visible changes in terms of color or construction). However, straw, coconut coir, composted cow manure, and Canadian sphagnum moss and wood pulp containers had an average rating of $2.9,2.7,1.4$, and 1.6 , respectively. Both shoot and root dry weights were greatest in plants produced in molded fiber and straw containers. The root to shoot dry weight ratio and days to anthesis was not significantly different among container types. Bract area index (a measurement derived to estimate bract area) was greatest for plants produced in molded fiber containers and lowest for those produced in the wheat starch containers. When adjusted for container height, final plant height was greatest in molded fiber containers and lowest in wheat starch containers. Plants produced in molded fiber containers, on average, exhibited the greatest height, bract area index, and total root and shoot weight, with no visible changes to container integrity. Based on these results, plant quality was not negatively impacted by any of the seven containers, though marketability of finished plants can be affected by container integrity.

$\mathrm{P}$ oinsettias are the most valuable potted flowering crop in the United States with a wholesale value over \$145 million for the 15 largest producing states [U.S. Department of Agriculture (USDA), 2010]. From 2008 to 2009 , total wholesale value decreased by $\$ 7$ million, reflecting both a decrease in the number of plants sold and price per 5 -inch or larger containers (USDA, 2010). In today's market, growers must find ways to add value to their poinsettia crops to sustain sales. An opportunity to do so exists by emphasizing the sustainable nature of green industry products given

Department of Horticulture and Landscape Architecture, Purdue University, West Lafayette, IN 47907. 2010

We gratefully acknowledge Landon Young, Rob Eddy, Dan Hahn, and Christopher Currey for greenhouse assistance and data analysis, funding from growers providing support for Purdue University floriculture research, and support from the Purdue Agricultural Experiment Station. We thank the Paul Ecke Ranch for plants, Conrad Fafard for growing substrate, Scotts Co. for fertilizer, and ITML for containers.

Use of trade names in this publication does not imply endorsement by Purdue University of products named nor criticism of similar ones not mentioned

${ }^{1}$ Corresponding author. E-mail: rglopez@purdue.edu. the increased environmental consciousness of consumers (Lifestyles of Health and Sustainability, 2010). Lopez et al. (2008) list packaging changes as one of the eight steps greenhouse operations can make toward becoming sustainable, an industry goal from both economic and public perception standpoints. Molded and extruded plastic containers have been the industry standard for years, both domestically and overseas because of favorable price, mechanical resistance qualities, and ability to be impregnated with color (Candido et al., 2008) and have also been highly customizable, providing growers a simple way to differentiate themselves in the marketplace. Increasing costs of petroleum resins used in manufacturing plastic containers and environmental impacts of plastic disposal, coupled with advanced technologies in biodegradable and compostable products and changing public perception, indicate an opportunity for competition by an alternative production container. A biodegradable or compostable container that potentially requires less fossil fuel to produce, does not present a disposal issue, potentially incorporates a waste byproduct, and markets the product in a new way for a targeted population segment has the ability to achieve the goal of added value for the consumer. The public perception of added-value and environmentally friendly packaging can translate not only into sales but into a higher price over the typically packaged commodity (Hall et al., 2010; Laroche et al., 2001). For example, Yue et al. (2010) found that a rice hull, straw, and wheat starch-derived bioresin container can generate a $\$ 0.58, \$ 0.37$, and $\$ 0.23$ premium, respectively, compared with the traditional plastic pot.

Unique to poinsettia production is its long cropping period and that it is a holiday interior floral product. The container is part of the final marketed product, unlike herbs, vegetable transplants, and bedding plants, where biodegradable and compostable containers have already made headway. In addition, because of its finite shelf life, it is an entirely disposable product, unlike the categories mentioned above (Candido et al., 2008). Candido et al. (2008) trialed poinsettia in conventional plastic, $100 \%$ bioplastic, and bioplastic containers made with $10 \%$ and $20 \%$ compostable materials and found that pot degradation increased with increasing percentage of compostable materials. Poinsettia fresh weight and bract number were highest for plants grown in the $20 \%$ compostable materials containers.

\begin{tabular}{llll}
\hline $\begin{array}{l}\text { Units } \\
\text { To convert U.S. to SI, } \\
\text { multiply by }\end{array}$ & U.S. unit & SI unit & $\begin{array}{l}\text { To convert SI to U.S., } \\
\text { multiply by }\end{array}$ \\
\hline 29.5735 & $\mathrm{fl} \mathrm{oz}$ & $\mathrm{mL}$ & 0.0338 \\
2.54 & inch(es) & $\mathrm{cm}$ & 0.3937 \\
25.4 & inch $(\mathrm{es})$ & $\mathrm{mm}$ & 0.0394 \\
1 & mmho/cm & $\mathrm{dS} \cdot \mathrm{m}^{-1}$ & 1 \\
28.3495 & $\mathrm{oz}$ & $\mathrm{g}$ & 0.0353 \\
1 & $\mathrm{ppm}$ & $\mathrm{mg} \cdot \mathrm{L}^{-1}$ & 1 \\
0.001 & $\mathrm{ppm}$ & $\mathrm{mL} \cdot \mathrm{L}^{-1}$ & 1000 \\
$\left({ }^{\circ} \mathrm{F}-32\right) \div 1.8$ & ${ }^{\circ} \mathrm{F}$ & ${ }^{\circ} \mathrm{C}$ & $\left(1.8 \times{ }^{\circ} \mathrm{C}\right)+32$ \\
& & &
\end{tabular}


Evans et al. (2010) performed various strength measurements on dry plastic, wood fiber, peat, composted cow manure, coconut coir, straw, rice hull, and paper containers and with saturated substrate only, finding that wet strength was compromised with peat containers. Plant quality parameters for bedding plants produced in plastic, peat, and poultry feather containers (Evans and Hensley, 2004) have been quantified. However, plant quality and container integrity measurements for a long-term crop where not only container strength but visual quality is important have not been done with both compostable and biodegradable containers (biocontainers).

Consumers desire a high-quality product irrespective of environmental implications (Hall et al., 2010). If a quality floral product could be achieved, a barrier to the adoption of sustainable containers in poinsettia production could be removed by reducing perceived risk (Hall et al., 2009). Therefore, our objectives were to determine both the feasibility and quality implications of growing a long-term crop in biocontainers.

\section{Materials and methods}

On 22 Aug. 2009, rooted cuttings of 'Eckespoint Classic Red' poinsettia were delivered from Paul Ecke Ranch (Encinitas, CA) to Purdue University in West Lafayette, IN (lat. $40^{\circ} \mathrm{N}$ ). Plants were transplanted on 2 Sept. 2009 into one of the eight container types filled with a commercial soilless substrate composed of $80 \%$ sphagnum moss and $20 \%$ perlite (Fafard CustomlP Mix; Conrad Fafard,
Agawam, MA). The container types were plastic, rice hull, Canadian sphagnum moss and wood pulp (Jiffy Pot), straw (StrawPot), coconut coir fiber, composted cow manure (CowPot), wheat starch-derived bioresin (OP47 Bio $\left.{ }^{\circledR}\right)$, and molded fiber (Table 1 ). Containers were filled with $1000 \mathrm{~mL}$ of substrate regardless of dimensions for all containers. Plants were pinched 2 weeks after transplant, and irrigated as necessary with acidified water supplemented with $15 \mathrm{~N}-2.2 \mathrm{P}-12.5 \mathrm{~K}$ water-soluble fertilizer (Peters Excel Cal-Mag; Scotts, Marysville, $\mathrm{OH}$ ) to provide the following at each irrigation $\left(\mathrm{mg} \cdot \mathrm{L}^{-1}\right)$ : 200 nitrogen $(\mathrm{N}), 29$ phosphorous $(\mathrm{P}), 167$ potassium $(\mathrm{K})$, 67 calcium $(\mathrm{Ca}), 27$ magnesium $(\mathrm{Mg})$, 1.0 iron $(\mathrm{Fe}), 0.24$ copper $(\mathrm{Cu})$ and boron $(\mathrm{B}), 0.5$ manganese $(\mathrm{Mn})$ and zinc $(\mathrm{Zn})$, and 0.1 molybdenum $(\mathrm{Mo})$. Irrigation water was supplemented with $93 \%$ sulfuric acid (Ulrich Chemical, Indianapolis, IN) at $0.08 \mathrm{~mL} \cdot \mathrm{L}^{-1}$ to reduce alkalinity to $100 \mathrm{mg} \cdot \mathrm{L}^{-1}$ and $\mathrm{pH}$ to a range of 5.7-6.0.

The plants were grown in a polycarbonate greenhouse with a doublelayer polyethylene roof, exhaust fan and evaporative cooling pad, and radiant hot-water heating controlled by an environmental computer (Wadsworth EnviroSTEP climate control computer; Wadsworth Control Systems, Arvada, $\mathrm{CO})$. The greenhouse day and night temperature set points were 24 and $19^{\circ} \mathrm{C}$, respectively. Plants were grown under ambient light with day extension lighting from an oscillating highpressure sodium lamp (Beamflicker; Parsource, Petaluma, CA) that delivered a photosynthetic photon flux varying between 3 and $59 \mu \mathrm{mol} \cdot \mathrm{m}^{-2} \cdot \mathrm{s}^{-1}$ at plant height [as measured with a quantum sensor (LI-COR Biosciences, Lincoln, NE)] from 1700 to $2200 \mathrm{HR}$. On 15 Oct., inductive short day (SD) photoperiods were initiated. Short days were achieved by covering the plants with an opaque cloth at $1600 \mathrm{HR}$ and retracting the cloth at $0800 \mathrm{HR}$. Environmental data [as measured with a weather station (WatchDog; Spectrum Technologies, Plainfield, IL)] are reported in Table 2.

Beginning on 10 Nov. 2009, weekly visual ratings were conducted on all eight container types. The visual rating scale is outlined in Table 3 . Weekly pour through substrate $\mathrm{pH}$ and electrical conductivity (EC) measurements were conducted. At visible anthesis (first pollen shed) of inflorescences on two different branches, the date, final plant height from the base of the pot to the top of the apical meristem, and bract length and width of the two flowering stems (widest diameter and diameter $90^{\circ}$ across) were recorded. Bract area index of each of the flowering stems was determined by using the formula for an ellipse $[($ long axis $\times$ short axis $\times \pi) \div 4]$ and averaged as a representation of total bract area. The bract area to height ratio was calculated by dividing bract area index by final plant height as a measure of the aesthetic ratio of "color" to height. Time to anthesis was calculated by subtracting the date that SD photoperiods were initiated from the date of anthesis. The plant tissue was harvested (shoots dissected from roots at substrate line) at anthesis and dried in a forced air oven (Sheldon

Table 1. Description of containers used to grow 'Eckespoint Classic Red' poinsettia for 14 weeks.

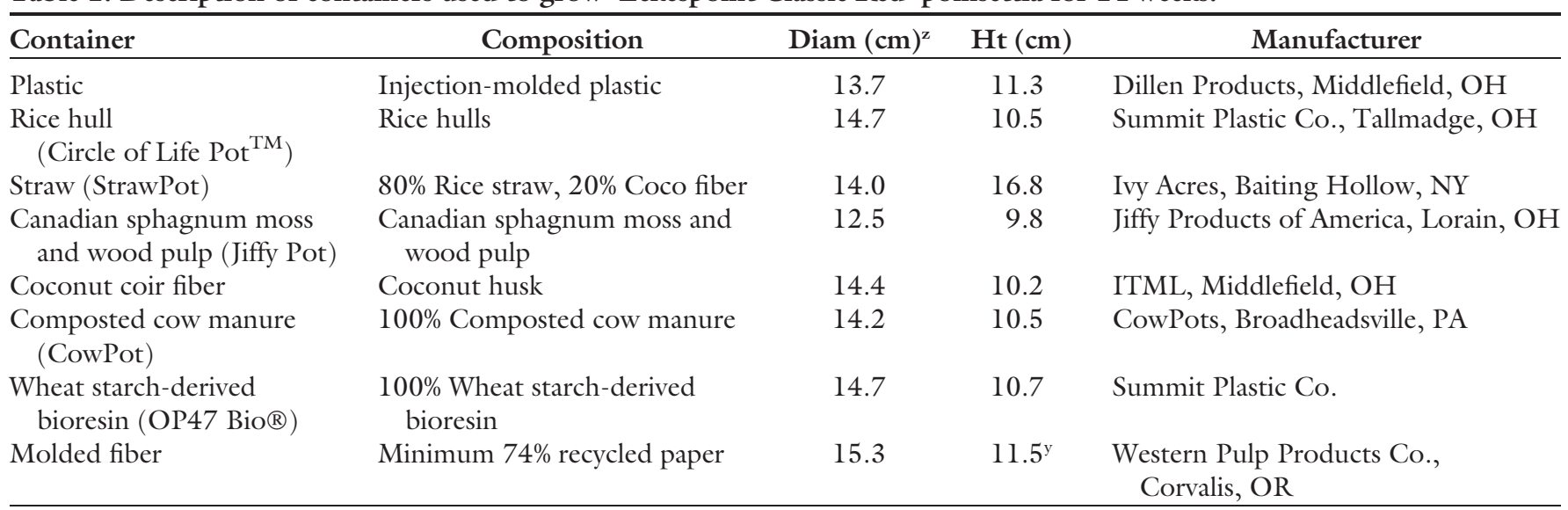

${ }^{\mathrm{z}} 1 \mathrm{~cm}=0.3937$ inch

${ }^{\mathrm{y}}$ Modified from original. 
Table 2. Average daily greenhouse air temperature and daily light integral (DLI) during each mo. for 'Eckespoint Classic Red' poinsettia planted in plastic, biodegradable, and compostable containers.

\begin{tabular}{lcc}
\hline Mo. & Air temp $\left[\text { mean } \pm \mathrm{sD}\left({ }^{\circ} \mathbf{C}\right)\right]^{\mathrm{z}}$ & DLI $\left(\mathbf{m o l} \cdot \mathrm{m}^{-2} \cdot \mathrm{d}^{-\mathbf{1}}\right)$ \\
\hline September & $21.8 \pm 2.0$ & 19.0 \\
October & $21.3 \pm 2.9$ & 8.8 \\
November & $21.7 \pm 2.3$ & 9.6 \\
December & $21.1 \pm 2.1$ & 6.5 \\
\hline
\end{tabular}

${ }^{z}\left(1.8 \times{ }^{\circ} \mathrm{C}\right)+32={ }^{\circ} \mathrm{F}$.

Table 3. Visual quality rating scale used for plastic (Dillen Products, Middlefield, $\mathrm{OH}$ ), rice hull [Circle of Life Pot $^{\mathrm{TM}}$ (Summit Plastic Co., Tallmadge, OH)], Canadian sphagnum moss and wood pulp [Jiffy Pot (Jiffy Products of America, Lorain, OH)], straw [StrawPot (Ivy Acres, Baiting Hollow, NY)], coconut coir fiber (ITML, Middlefield, OH), composted cow manure [CowPot (CowPots, Broadheadsville, PA)], wheat starch-derived bioresin [OP47 Bio ${ }^{\circledR}$ (Summit Plastic Co.)], and molded fiber (Western Pulp Products, Corvalis, OR) containers. 'Eckespoint Classic Red' poinsettia was grown in the containers for 14 weeks.

\begin{tabular}{ll}
\hline Rating scale & \multicolumn{1}{c}{ Description } \\
\hline 5 & Intact, no visible changes in terms of color or construction. \\
4 & Intact, visible changes in color or slight container integrity change. \\
3 & Intact, visible changes in color highly noticeable and unappealing. \\
2 & Container integrity compromised somewhat. \\
1 & Container integrity compromised substantially. \\
\hline
\end{tabular}

Manufacturing, Cornelius, OR) at $70{ }^{\circ} \mathrm{C}$, and shoot and root dry weight were measured. The root to shoot dry weight ratio was calculated. The experiment used a completely randomized design. There were eight replicates (individual plants) per container treatment. Data were analyzed using SPSS (version 18.0; SPSS, Chicago, IL).

\section{Results}

As the Canadian sphagnum moss and wood pulp containers could only accommodate $75 \%$ of the substrate volume of the other containers, only the comparison of container integrity and marketability determination was made for these containers. Container integrity ratings fell into three broad categories (Table 4). One group, consisting of containers receiving visual ratings of 5 as they were unaffected by environmental growing conditions and showed no visible changes over the 14-week growing period, included plastic, rice hull, wheat starch-derived bioresin, and molded fiber. A second group consisting of straw and coconut coir had visual ratings of 2.9 and 2.8 , respectively, at anthesis. These containers displayed significant changes in visual quality over the nonaffected group, and although unappealing, container integrity was not compromised. The final two containers, $\mathrm{Ca}-$ nadian sphagnum moss and wood pulp and composted cow manure, with visual ratings of 1.6 and 1.4 , respectively, exhibited a significantly lower and unacceptable visual quality rating, indicating that degradation took place during production to the degree that containers could not be handled and therefore unmarketable.

Marketable plants were produced in all container types used in the study. All plants met the minimum marketable height for commercial production of $35.6 \mathrm{~cm}$. Some were above the maximum marketable height of $40.6 \mathrm{~cm}$ as no plant growth regulators were applied (Table 5). Final height of plants grown in molded fiber and straw was significantly greater than plants grown in plastic, wheat starch-derived bioresin, and coconut coir. Bract area index of plants grown in molded fiber containers was significantly greater $(22 \%)$ than for plants grown in the wheat starch-derived bioresin containers. Container type had no significant effect on bract area to height ratio or days to anthesis. Time to anthesis across all treatments was 55 to $56 \mathrm{~d}$.

Root dry weight of plants grown in molded fiber containers was significantly greater than those plants grown in plastic and wheat starch-derived bioresin containers. There was no significant difference in shoot dry weight among container types.

There was a significant difference in the final substrate $\mathrm{pH}$ in the straw container, $\mathrm{pH} 7.0$ compared with an average $\mathrm{pH}$ of 6.3 for the other six container types. Final substrate EC was within the acceptable range for poinsettia (pour through test range 2.2-3.8 $\mathrm{dS} \cdot \mathrm{m}^{-1}$ ) for all container types.

\section{Discussion}

Paper containers with binder (molded fiber) proved to be resistant to degradation during a 14-week poinsettia production cycle, in the same category with plastic and plastic-appearing containers composed of rice hull and wheat starch-derived bioresin. Straw and coconut coir containers maintained their physical integrity to the extent of being handled, and so they could be used for long-term production where the presence of algae on the container would not be as critical. Composted cow manure and sphagnum moss and wood pulp containers, designed to be directly planted in the ground, would not hold up to handling after 14 weeks and would be limited to shorter term crops such as bedding and vegetable transplants. Candido et al. (2008) had similar results with poinsettia, whereby containers with $10 \%$ and $20 \%$ compostable materials $(90 \%$ and $80 \%$ bioresin, respectively) displayed visual lesions, while traditional plastic and $100 \%$ bioresin did not. Evans et al. (2010) performed a study of physical properties on the same container types used in this study with annuals and found significant algal and fungal growth on peat pots only after 6 weeks. Plant material, substrate composition, and fertilizer used in addition to watering regime could influence the presence of algal and fungal growth on containers.

Plants grown in molded fiber containers were taller, had larger bract area indexes, and had greater root weight than plants grown in wheat starch-derived bioresin containers. There was no significant difference in shoot dry weight among the seven container types studied. Candido et al. (2008) found that $80 \%$ bioresin $/ 20 \%$ compostable material containers produced poinsettia plants that had significantly greater stem fresh weight, leaf and bract number, and fresh weight per 
plant over plants grown in plastic, $100 \%$ bioresin, and $90 \%$ bioresin/ $10 \%$ compostable material containers. Evans and Hensley (2004) did not find significant differences in shoot weight when impatiens (Impatiens walleriana) and vinca (Catharanthus roseus) were grown in plastic or peat containers and irrigated as needed as opposed to $25 \%$ surface drying. Under similar uniform irrigation practices used in our study, dry shoot weight was greater for marigold (Tagetes patula), vinca, geranium (Pelargonium $\times$ hortorum), and tomato (Solanum lycopersicum), but not impatiens, in plastic vs. peat or feather containers. This would indicate that fresh or dry weight results in various containers are highly dependent on species grown and watering regime.

Table 4. Visual quality ratings of plastic (Dillen Products, Middlefield, $\mathrm{OH}$ ), rice hull [Circle of Life Pot ${ }^{\mathrm{TM}}$ (Summit Plastic Co., Tallmadge, OH)], Canadian sphagnum moss and wood pulp [Jiffy Pot (Jiffy Products of America, Lorain, $\mathrm{OH}$ )], straw [StrawPot (Ivy Acres, Baiting Hollow, NY)], coconut coir fiber (ITML, Middlefield, OH), composted cow manure [CowPot (CowPots, Broadheadsville, PA)], wheat starch-derived bioresin [OP47 Bio ${ }^{\circledR}$ (Summit Plastic Co.)], and molded fiber (Western Pulp Products, Corvalis, OR) containers after 10, 11, 12, 13, and 14 weeks. 'Eckespoint Classic Red' poinsettia was grown in the containers for 14 weeks.

\begin{tabular}{|c|c|c|c|c|c|}
\hline \multirow[b]{3}{*}{ Container } & \multicolumn{5}{|c|}{ Time after transplanting (wk) } \\
\hline & 10 & 11 & 12 & 13 & 14 \\
\hline & \multicolumn{5}{|c|}{ Visual quality rating $(1-5 \text { scale })^{\mathrm{z}}$} \\
\hline Plastic & $5.0 \mathrm{a}^{\mathrm{y}} \mathrm{A}^{\mathrm{x}}$ & $5.0 \mathrm{aA}$ & $5.0 \mathrm{aA}$ & $5.0 \mathrm{aA}$ & $5.0 \mathrm{aA}$ \\
\hline Rice hull & $5.0 \mathrm{aA}$ & $5.0 \mathrm{aA}$ & $5.0 \mathrm{aA}$ & $5.0 \mathrm{aA}$ & $5.0 \mathrm{aA}$ \\
\hline Straw & $3.0 \mathrm{cA}$ & $3.0 \mathrm{bcA}$ & $3.0 \mathrm{bA}$ & $3.0 \mathrm{bA}$ & $2.9 \mathrm{bA}$ \\
\hline Peat moss and wood pulp & $2.6 \mathrm{cA}$ & $2.6 \mathrm{cA}$ & $2.5 \mathrm{cdAB}$ & $2.3 \mathrm{cAB}$ & $1.6 \mathrm{cB}$ \\
\hline Coconut coir fiber & $4.0 \mathrm{bA}$ & $3.5 \mathrm{bAB}$ & $2.9 \mathrm{bcBC}$ & $2.8 \mathrm{bC}$ & $2.8 \mathrm{bC}$ \\
\hline Composted cow manure & $2.8 \mathrm{cA}$ & $2.6 \mathrm{cA}$ & $2.4 \mathrm{dA}$ & $2.3 \mathrm{cA}$ & $1.4 \mathrm{cB}$ \\
\hline Wheat starch & $5.0 \mathrm{aA}$ & $5.0 \mathrm{aA}$ & $5.0 \mathrm{aA}$ & $5.0 \mathrm{aA}$ & $5.0 \mathrm{aA}$ \\
\hline Molded fiber & $5.0 \mathrm{aA}$ & $5.0 \mathrm{aA}$ & $5.0 \mathrm{aA}$ & $5.0 \mathrm{aA}$ & $5.0 \mathrm{aA}$ \\
\hline Container & * & & & & \\
\hline Week & * & & & & \\
\hline Container $\times$ Week & * & & & & \\
\hline
\end{tabular}

${ }^{\mathrm{z}} 1$ = container integrity compromised substantially, $5=$ container was intact, no visible changes in terms of color or construction (Table 3 ).

'Within-column means followed by different lower-case letters are significantly different by Tukey's honestly significant difference (HSD) test at $P \leq 0.05$.

${ }^{x}$ Within-row means followed by different upper-case letters are significantly different by Tukey's HSD test at $P \leq$ 0.05 .

* Significant at $P \leq 0.001$

Table 5. Bract area index, height, bract area to height ratio, time to anthesis (first pollen shed), root and shoot dry weight, and final $\mathrm{pH}$ and electrical conductivity (EC) at anthesis of 'Eckespoint Prestige' poinsettias grown in plastic (Dillen Products, Middlefield, OH), rice hull [Circle of Life Pot ${ }^{\mathrm{TM}}$ (Summit Plastic Co., Tallmadge, OH)], straw [StrawPot (Ivy Acres, Baiting Hollow, NY)], coconut coir fiber (ITML, Middlefield, OH), composted cow manure [CowPot (CowPots, Broadheadsville, PA)], wheat starch-derived bioresin [OP47 Bio ${ }^{\circledR}$ (Summit Plastic Co.)], and molded fiber (Western Pulp Products, Corvalis, OR) containers.

\begin{tabular}{lcccccccc}
\hline Container & $\begin{array}{c}\text { Bract area } \\
\text { index }\left(\mathrm{cm}^{2}\right)^{\mathrm{z}}\end{array}$ & $\mathbf{H t}(\mathrm{cm})^{\mathrm{z}}$ & $\begin{array}{c}\text { Bract area: } \\
\text { height ratio }\end{array}$ & $\begin{array}{c}\text { Time to } \\
\text { anthesis }(\mathrm{d})\end{array}$ & $\begin{array}{c}\text { Root dry } \\
\mathbf{w t}(\mathrm{g})^{\mathrm{z}}\end{array}$ & $\begin{array}{c}\text { Shoot } \\
\text { dry wt }(\mathrm{g})^{\mathrm{z}}\end{array}$ & Final $\mathrm{pH}$ & Final EC \\
\hline Plastic & $1096.5 \mathrm{ab}^{\mathrm{y}}$ & $41.3 \mathrm{~b}$ & $26.7 \mathrm{a}$ & $55.5 \mathrm{a}$ & $3.1 \mathrm{bc}$ & $28.3 \mathrm{a}$ & $6.2 \mathrm{c}$ & $3.08 \mathrm{ab}$ \\
$\begin{array}{l}\text { Rice hull } \\
\text { Straw }\end{array}$ & $1270.5 \mathrm{ab}$ & $43.3 \mathrm{ab}$ & $29.6 \mathrm{a}$ & $55.0 \mathrm{a}$ & $3.4 \mathrm{abc}$ & $32.5 \mathrm{a}$ & $6.4 \mathrm{bc}$ & $3.28 \mathrm{ab}$ \\
$\begin{array}{l}\text { Coconut coir } \\
\quad \text { fiber }\end{array}$ & $1267.5 \mathrm{ab}$ & $47.5 \mathrm{a}$ & $26.7 \mathrm{a}$ & $55.1 \mathrm{a}$ & $3.9 \mathrm{ab}$ & $34.8 \mathrm{a}$ & $7.0 \mathrm{a}$ & $3.50 \mathrm{ab}$ \\
$\begin{array}{l}\text { Composted } \\
\quad \text { Cow manure }\end{array}$ & $1202.8 \mathrm{ab}$ & $40.8 \mathrm{~b}$ & $30.2 \mathrm{a}$ & $56.0 \mathrm{a}$ & $3.5 \mathrm{abc}$ & $29.4 \mathrm{a}$ & $6.4 \mathrm{~b}$ & $4.32 \mathrm{a}$ \\
$\begin{array}{l}\text { Wheat starch } \\
\begin{array}{l}\text { Molded fiber } \\
P \text { value }\end{array}\end{array}$ & $1140.6 \mathrm{ab}$ & $44.1 \mathrm{ab}$ & $26.0 \mathrm{a}$ & $55.4 \mathrm{a}$ & $3.8 \mathrm{bc}$ & $29.8 \mathrm{a}$ & $6.4 \mathrm{~b}$ & $2.94 \mathrm{~b}$ \\
\hline
\end{tabular}

${ }^{\mathrm{z}} 1 \mathrm{~cm}^{2}=0.1550$ inch $^{2}, 1 \mathrm{~cm}=0.3937$ inch, $1 \mathrm{~g}=0.0353 \mathrm{oz}$.

${ }^{y}$ Within-column means followed by different lower case letters are significantly different by Tukey's honestly significant difference (HSD) test at $P \leq 0.05$. 
although not necessarily of consequence to plant growth. Containers composed of composted cow manure did not result in an EC greater than the other six containers, although they are made of $100 \%$ composted cow manure and could conceivably contribute $\mathrm{N}$ to the substrate solution when moistened (Table 5 ). Evans and Hensley (2004) indicated that the $\approx 13 \%$ organic $N$ content by weight of feather pots could have contributed to plant growth of marigold, vinca, and geranium in those containers. In this study, the final substrate EC of coconut coir containers was significantly higher than for the composted cow manure container (Table 5).

\section{Conclusions}

It was possible to produce a longterm-poinsettia crop of acceptable plant quality in the eight container types used in this study. Algal and fungal growth and breakage can be limiting factors to the use of Canadian sphagnum moss and wood pulp, composted cow manure, straw, and coconut coir containers. The most promising containers for commercial poinsettia production in regard to the above limitations are molded fiber, rice hull, and wheat starch-derived bioresin. There is evidence that plant growth may be superior in molded fiber and rice hull containers over wheat starch-derived bioresin as wheat starch-derived bioresin containers were similar to plastic in terms of plant growth parameters. The marketing advantages and "perceived value added" of a poinsettia produced in a biodegradable or compostable container is encouraging. However, modifications to current practices, especially in regard to irrigation, will need to be explored before some biocontainers can be considered suitable for poinsettia or other long-term crops.

\section{Literature cited}

Candido, V., D. Castronuovo, C. Manera, and V. Miccolis. 2008. Poinsettia (Euphorbia pulcherrima) cultivation in biodegradable pots: Mechanical and agronomical behavior of pots and plant traits. Acta Hort. 801:1563-1570.

Evans, M.R. and D.L. Hensley. 2004. Plant growth in plastic, peat, and processed poultry feather fiber growing containers. HortScience 39:1012-1014.

Evans, M.R. and D. Karcher. 2004. Properties of plastic, peat, and processed poultry feather fiber growing containers. HortScience 39:1008-1011.

Evans, M.R., M. Taylor, and J. Kuehny. 2010. Physical properties of biocontainers for greenhouse crops production. HortTechnology 20:549-555.

Hall, C.R., B.L. Campbell, B.K. Behe, C. Yue, R.G. Lopez, and J.H. Dennis. 2010. The appeal of biodegradable packaging to floral consumers. HortScience 45:583591.

Hall, T.J., J.H. Dennis, R.G. Lopez, and M.I. Marshall. 2009. Factors affecting growers' willingness to adopt sustainable floriculture practices. HortScience 44: 1346-1351.

Hammer, P.A. 2011. Roots. Growertalks 74:24.

Laroche, M., J. Bergeron, and G. BarbaroForleo. 2001. Targeting consumers who are willing to pay more for environmentally friendly products. J. Consum. Mktg. 18: 503-520.

Lifestyles of Health and Sustainability. 2010. 1 June 2011. <http:/ /www.lohas.com/ about>.

Lopez, R.G., S.E. Burnett, B.A. Krug, and J.H. Dennis. 2008. 8 steps to take to become sustainable. Greenhouse Mgt. Production 28:26, 28-29, 50.

Minuto, G., A. Minuto, L. Pisi, F. Tinivella, S. Guerrini, M. Capurro, and I. Amprimo. 2007. Use of compostable pots for potted ornamental plant production. Acta Hort. 801:367-372.

U.S. Department of Agriculture. 2010. Floriculture crops 2009 summary. 22 Mar. 2010. <http://usda.mannlib.cornell. edu/usda/nass/FlorCrop//2010s/ 2010/FlorCrop-06-04-2010_revision.pdfs.

Yue, C., C.R. Hall, B.K. Behe, B.L. Campbell, J.H. Dennis, and R.G. Lopez. 2010. Are consumers willing to pay more for biodegradable containers than for plastic ones? Evidence from hypothetical conjoint analysis and non-hypothetical experimental auctions. J. Agr. Appl. Econ. 42:757-772. 